\title{
Rectal Villous Adenoma with McKittrick-Wheelock Syndrome: Report of a Rare Case
}

\author{
Yu-Hung Chen Jung-Cheng Kang Huang-Jen Lai \\ Department of Colorectal Surgery, Buddhist Tzu Chi General Hospital, Hualien, Taiwan
}

\author{
Keywords \\ Villous adenoma - McKittrick-Wheelock syndrome . \\ Neoplastic cholera
}

\section{Summary}

Background: McKittrick-Wheelock syndrome mostly results from colorectal villous adenoma and is characterized by dehydration, hyponatremia, hypokalemia, and prerenal azotemia. Case Report: We report the case of an 84-year-old patient with rectal villous adenoma, presenting with chronic mucous diarrhea for 2 years and subsequent prerenal azotemia. After fluid and electrolyte replenishment, the patient underwent proctectomy and recovered completely. Conclusion: According to a review of the literature, we suggest that surgical resection can achieve a complete recovery.

\section{Introduction}

Large villous adenoma in the colon and rectum can sometimes be associated with secretory diarrhea, which can result in dehydration, hyponatremia, hypokalemia, prerenal azotemia, and further circulatory collapse. This adenoma was first described in 1954 by McKittrick and Wheelock and was thus named McKittrick-Wheelock syndrome [1]. Recent studies have demonstrated a role for prostaglandin E2 (PGE2) and cAMP in the secretory nature of the tumor [2].

McKittrick-Wheelock syndrome should be considered in patients who present with electrolyte insufficiency and prere-

\begin{abstract}
Schlüsselwörter
Villöses Adenom - McKittrick-Wheelock-Syndrom . Neoplastische Cholera

Zusammenfassung

Hintergrund: Das McKittrick-Wheelock-Syndrom resultiert meist aus kolorektalen villösen Adenomen und wird durch Dehydration, Hyponatriämie, Hypokaliämie und prärenale Azotämie charakterisiert. Fallbericht: Im Folgenden berichten wir über einen 84-jährigen Patienten mit rektalem villösem Adenom, der seit 2 Jahren chronisch schleimigen Durchfall hatte und eine anschließende prärenale Azotämie aufwies. Nach der Auffrischung des Flüssigkeits- und Elektrolythaushalts unterzog sich der Patient einer Proktektomie und erholte sich danach vollständig. Schlussfolgerung: Nach der Überprüfung der Literatur weisen wir darauf hin, dass eine chirurgische Resektion eine vollständige Genesung herbeiführen kann.
\end{abstract}

nal azotemia accompanied by chronic watery diarrhea. The imbalance in electrolytes and fluid depletion can result in syncope and life-threatening cardiac arrhythmia. Thus, early diagnosis is essential to enable initiation of treatment by correcting electrolyte imbalance and replenishing fluids. With a stabilization of electrolytes and circulation, the definitive treatment is a resection of the tumor. Here, we report a case of rectal villous adenoma with McKittrick-Wheelock syndrome. We also analyze and discuss cases described in the literature to enhance recognition of this lethal condition and to discuss the possible pathogenesis.

\begin{tabular}{ll}
\hline KARGER & @ 2013 S. Karger GmbH, Freiburg \\
1662-6664/13/0291-0055\$38.00/0 \\
$\begin{array}{l}\text { Fax +49 761 452 07 14 } \\
\text { Information@Karger.com } \\
\text { www.karger.com }\end{array}$ & $\begin{array}{l}\text { Accessible online at: } \\
\text { www.karger.com/vim }\end{array}$
\end{tabular}


An 84-year-old male presented with a 2-year history of chronic watery and mucous diarrhea, and general malaise and poor appetite within the month before admission. The patient denied having hematochezia and body weight loss or using laxatives. No family members had developed similar symptoms. After admission, the diarrhea continued despite no oral intake.

The patient's body temperature was $36.6^{\circ} \mathrm{C}$, heart rate was 86 beats/ min, respiratory rate was 15 breaths/min, and blood pressure was 116/85 $\mathrm{mm} \mathrm{Hg}$. The patient was alert and clear-thinking. The abdomen was soft and flat. Normoactive bowel sounds were audible. During palpation of the abdomen, there was no tenderness and no palpable mass. No hepatomegaly or splenomegaly was observed. A complete blood count revealed a white blood cell count of 19,420/ul, hemoglobin was $9.9 \mathrm{~g} / \mathrm{dl}$, and platelet count was 504,000/ $\mathrm{l}$. Serum creatinine and blood urea nitrogen levels were 1.9 and $36 \mathrm{mg} / \mathrm{dl}$, respectively. Serum sodium and potassium levels were 129 and $2.8 \mathrm{mmol} / \mathrm{l}$, respectively. After hydration and correction of dyselectrolytemia, serum creatinine and blood urea nitrogen levels were 1.4 and $35 \mathrm{mg} / \mathrm{dl}$, respectively. Serum sodium and potassium were within normal limits.

For evaluation of chronic diarrhea, a colonoscopy was performed and revealed a tumor of soft texture in the middle rectum (fig. 1). A biopsy was taken and a pathological examination revealed villous adenoma. Computerized tomography of the abdomen to the pelvis also showed the presence of a villous tumor inside the rectal lumen without signs of local invasion or distal metastasis.

The patient then underwent proctectomy. Grossly, the tumor occupied the entire circumference of the rectal lumen; villous projections were observed and the size was $10 \times 8 \times 1 \mathrm{~cm}^{3}$ (fig. 2). Pathological examination revealed no evidence of malignant transformation. After resection of the tumor, the patient had no further diarrhea, and serum creatinine and blood urea nitrogen were recovered to 1.1 and $29 \mathrm{mg} / \mathrm{dl}$, respectively.

\section{Discussion}

Rectal villous adenoma is the most common tumor responsible for McKittrick-Wheelock syndrome. The tumors are mostly located in the rectum and sigmoid colon. Typical manifestations include large volumes of secretory diarrhea, severe electrolyte imbalance (mainly hypokalemia, hyponatremia, hypochloremia, and metabolic acidosis), and prerenal azotemia. With extreme depletion, hypovolemic shock or lifethreatening arrhythmia may occur. During a review of the English literature we found some case reports describing this disorder (table 1). An analysis of demographics in this series of studies revealed that there were 24 women (60\%) and 16 men (40\%). Ages ranged from 30 to 82 years, with an average age of 66 years. Most patients were 60 to 80 years old. Among the 41 patients, there were 29 cases of rectal tumor. All patients had a history of chronic mucoid or watery diarrhea for at least 3 weeks, which lasted up to 5 years. There was a trend observed that, with medical progress, less time was spent for diagnosis of the disease. Most of the patients reported a complete recovery without recurrence of the tumor, even when symptoms were severe, such as hypovolemic shock and lifethreatening arrhythmia. The only mortalities reported were from the study by Davis et al. [3]. An analysis of the 22 cases

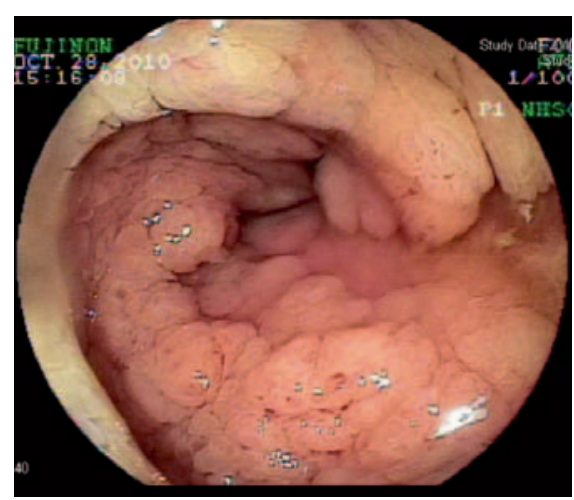

Fig. 1. A circumferential tumor with villous projections was noticed by colon fibroscopy $8 \mathrm{~cm}$ from the anal verge. There was also copious mucus covering on the surface of the tumor.

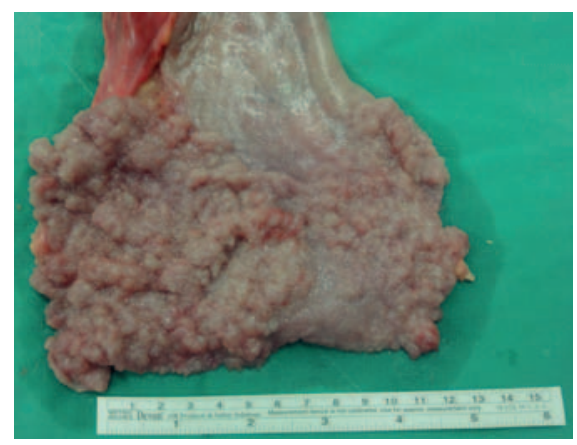

reported by Davis et al. revealed that the 5 reported mortalities did not undergo complete resection of the tumor and died because of severe fluid insufficiency and electrolyte imbalance. In a search of all the English literature on McKittrickWheelock syndrome, the mortality rate reported was about $12 \%$. However, when mortality is considered after surgical resection, it is nearly $0 \%$.

Several studies have demonstrated that PGE2 is elevated in the rectal secretion of patients with McKittrick-Wheelock syndrome and have detected a higher concentration of intracellular cAMP [2]. This biochemical change further induces electrolyte efflux (including sodium, potassium, and chloride), and water is then drawn out of the rectum. This results in prerenal azotemia and electrolyte insufficiency [14].

Because of the role of PGE2 in McKittrick-Wheelock syndrome, indomethacin, a nonsteroid anti-inflammatory drug, has been used to treat this syndrome. Steven et al. [4], Cutrin Pietro et al. [5], and Smelt et al. [6] have reported patients with McKittrick-Wheelock syndrome in whom indomethacin was used [4-6]. According to their reports, the hydroelectrolyte imbalance in these patients improved after indomethacin use. However, it deteriorated soon after the discontinuation of indomethacin. Most other studies concerning patients with McKittrick-Wheelock syndrome did not include the use of indomethacin; after electrolyte fluid supplement, the patients were given surgical resections and achieved complete recovery instead. Compared with simply treating with an aggressive fluid and electrolyte supply, indomethacin may provide no benefit in the preoperative control of hydroelectrolyte imbal- 


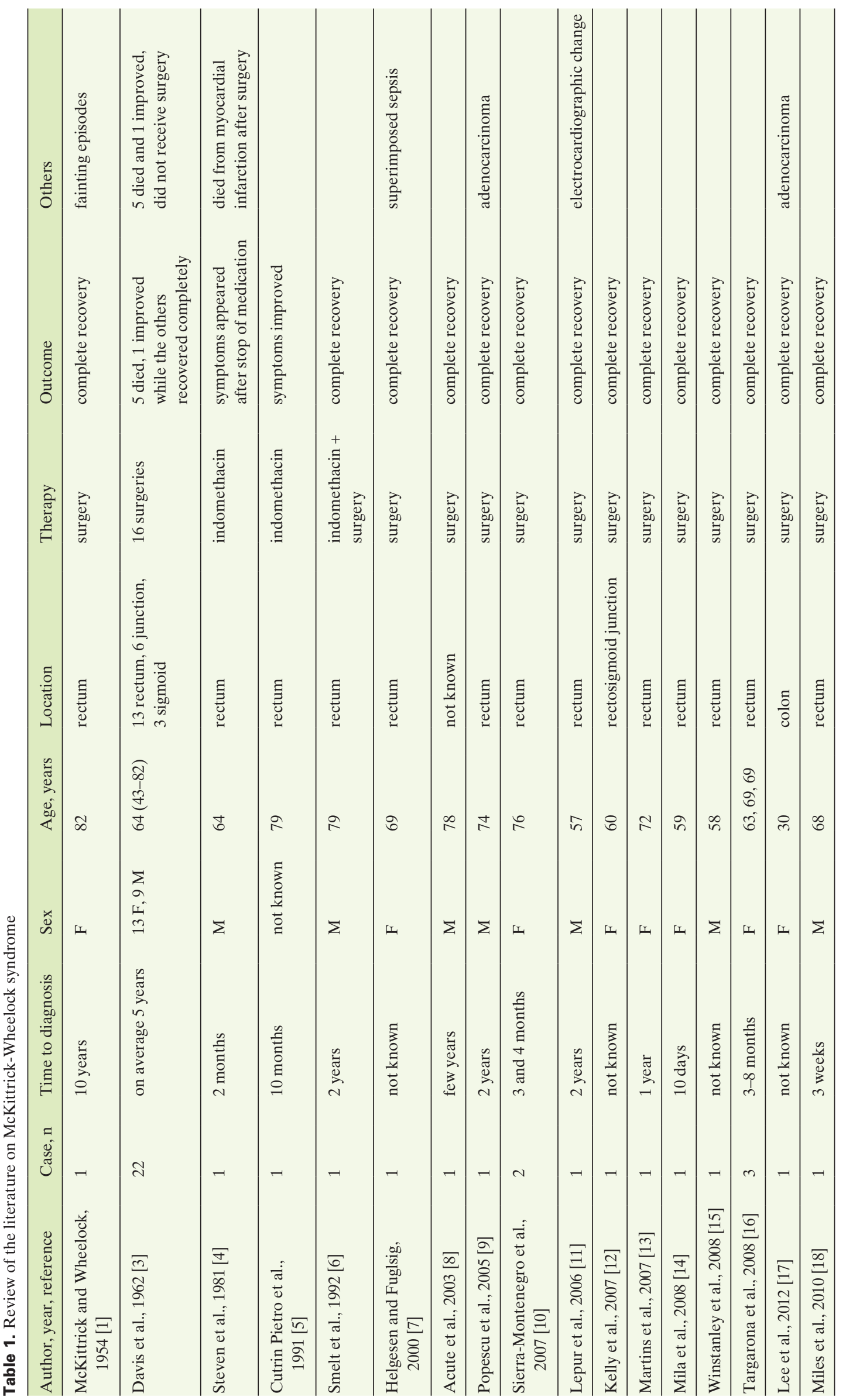


ance. Firstly, McKittrick-Wheelock syndrome is characterized by prerenal azotemia, and indomethacin, as a nonsteroid antiinflammatory drug, may cause further deterioration of the renal function. Secondly, as seen in the reported literature, malignant glandular cells can be found in such tumors $[11,17]$. Indomethacin treatment may delay surgery and investigation of histopathology. Thirdly, surgery remains the definitive treatment for McKittrick-Wheelock syndrome, and the reported literature shows that indomethacin use does not achieve a better outcome.

We suggest that patients with chronic diarrhea, especially elderly patients, should receive colonoscopies and treatment early to prevent the potentially life-threatening McKittrickWheelock syndrome. According to the literature, indometh- acin treatment can improve the hydroelectrolyte imbalance; however, it does not eradicate the disease. In addition, indomethacin may further aggravate renal function and hamper the investigation of possible malignancy. In contrast, surgical treatment can achieve a recovery of almost $100 \%$ without reported mortality. Therefore, we suggest that patients with McKittrick-Wheelock syndrome should undergo a complete resection of the tumors.

\section{Disclosure Statement}

The authors have no commercial associations or sources of financial support that might pose a conflict of interest.

\section{References}

1 McKittrick LS, Wheelock FC Jr: Carcinoma of the Colon. Springfield, IL, Charles C. Thomas, 1954 pp 61-63.

2 Jacob H, Schlondorff D, Onge G, Bernstein LH: Villous adenoma depletion syndrome. Evidence for a cyclic nucleotide-mediated diarrhea. Dig Dis Sci 1985;30:637-641.

$\checkmark 3$ Davis JE, Seavey PW, Sessions JT: Villous adenomas of the rectum and sigmoid colon with severe fluid and electrolyte depletion. Ann Surg 1962;155: 806-812.

4 Steven K, Lange P, Bukhave K, Rask-Madsen J: Prostaglandin E2-mediated secretory diarrhea in villous adenoma of rectum: effect of treatment with indomethacin. Gastroenterology 1981;80:1562-1566.

$\checkmark 5$ Cutrin Prieto C, Casal Iglesias L, Batalla Eiras A, Meniño Olveira MJ, Diéguez Gómez P, Lorenzo Zúniga V: Treatment with indomethacin for the control of the metabolic disorder caused by a villous adenoma of the rectum (article in Spanish). An Med Interna 1991;8:345-346.

6 Smelt AH, Meinders AE, Hoekman K, Noort WA, Keirse MJ: Secretory diarrhea in villous adenoma of rectum: effect of treatment with somatostatin and indomethacin. Prostaglandins 1992;43:567-572.
7 Helgesen A, Fuglsig S: Villous adenoma of the rectum with electrolyte imbalance. McKittrick-Wheelock syndrome (article in Danish). Ugeskr Laeger 2000;162:4272-4273.

8 Acute G, Griciūte L, Tamosaitis A, Grazulis S: Renal failure due to a villous adenoma (article in Lithuanian). Medicina (Kaunas) 2003;39(suppl 1): 48-50.

9 Popescu A, Orban-Schiopu AM, Becheanu G, Diculescu M: McKittrick-Wheelock syndrome - a rare cause of acute renal failure. Rom J Gastroenterol 2005;14:63-66.

10 Sierra-Montenegro E, Rocha-Ramírez JL, Villaneuva-Sáenz E, de la Serna-Ortiz I, FernándezRivero JM, Soto-Quirino R: Villous adenoma of the rectum with severe hydroelectric alterations. Report of two cases (article in Spanish). Cir Cir 2007:75:377-379.

11 Lepur D, Klinar I, Mise B, Himbele J, Vranjican Z, Barsić B: McKittrick-Wheelock syndrome: a rare cause of diarrhoea. Eur J Gastroenterol Hepatol 2006;18:557-559.

12 Kelly S, Lee P, Robertson G: Profound hypokalaemia secondary to a large rectosigmoid villous tumour. N Z Med J 2007;120:U2514.
13 Martins HS, Brandão-Neto RA, de Carvalho AL, Santana AN, Aguiar FJ, Scalabrini-Neto A, Velasco IT: McKittrick-Wheelock syndrome: a cause of severe hydro-electrolyte disorders in ED. Am J Emerg Med 2007;25:1083.e1-3.

14 Mila R, Grille S, Laurini M, Lapiedra D, Bagattini JC: McKittrick-Wheelock syndrome: report of one case (article in Spanish). Rev Med Chil 2008;136: 900-904.

15 Winstanley V, Little MA, Wadsworth C, Cohen P, Martin NM: The McKittrick-Wheelock syndrome: a case of acute renal failure due to neoplastic cholera. Ren Fail 2008;30:469-473.

16 Targarona EM, Hernandez PM, Balague C, Martinez C, Hernández J, Pulido D, Berindoague R, Trias M: McKittrick-Wheelock syndrome treated by laparoscopy: report of 3 cases. Surg Laparosc Endosc Percutan Tech 2008;18:536-538.

17 Lee YS, Lin HJ, Chen KT: McKittrick-Wheelock syndrome: a rare cause of life-threatening electrolyte disturbances and volume depletion. J Emerg Med 2012;43:e171-173.

18 Miles LF, Wakeman CJ, Farmer KC: Giant villous adenoma presenting as McKittrick-Wheelock syndrome and pseudo-obstruction. Med J Aust 2010; 192:225-227. 